\title{
Evaluation of Ligninolytic Activity of Fungal Pathogens Isolated from Parthenium Weed
}

\author{
Manpreet Kaur, Neeraj Kumar Aggarwal", Anita Yadav, Ranjan Gupta \\ Department of Microbiology, Kurukshetra University, India
}

Copyright $\bigcirc 2016$ by authors, all rights reserved. Authors agree that this article remains permanently open access under the terms of the Creative Commons Attribution License 4.0 International License

\begin{abstract}
In the present investigation five pathogenic fungal isolates such as Alternaria alternata, Alternaria sp. PMK1, Alternaria sp. PMK2, Alternaria macrospora MKP2 and Alternaria macrospora MKP4 were isolated from diseased leaves of parthenium plant and found to be pathogenic to this weed. Isolated pathogens were screened qualitatively and quantitatively for ligninolytic activity. All the fungal pathogens were preliminary screened by qualitative assay and showed positive results by zone formation on respective agar plates. In quantitative assay, all the isolates of Alternaria showed the production of one or the other ligninolytic enzymes. Enzymes of the pathogenic fungi are degraders of the polysaccharides available in the host plants and the strong enzymatic activities indicating the importance of the cell wall degrading enzymes in pathogenesis and potential of these pathogenic fungi to be used as a biocontrol agent against parthenium weed.
\end{abstract}

Keywords Alternaria, Biocontrol, Ligninolytic, Parthenium, Pathogenic

\section{Introduction}

Parthenium hysterophorus L. an exotic, pernicious weed is considered as one of the most troublesome weeds for agricultural sector by virtue of its high ecological amplitude and adaptability [1]. P. hysterophorus harbours a diversity of pathogenic fungi, as shown recently by Aggarwal et al. [2]. Pathogenic fungi occupy a relatively unexplored area in microorganism enzymes with different potentialities. Plant biomass is made up of mostly polysaccharides. The plant cell wall is comprised of cellulose, which makes up the structural framework of the wall, along with the matrix molecules hemicellulose, glycoproteins, pectin and lignin [3]. Enzymes play a fundamental role in host-parasite interaction and are involved not only in the initial entry of the pathogen and its spread within the plant tissue but also in the degradation of host tissue into metabolites which the parasite can utilize [4].
Lignin is an aromatic and heterogeneous constituent of plant cell wall that physically surrounds and protects the carbohydrate polymers from enzymatic hydrolysis and provide resistance towards microbial attack [5]. Therefore accessibility and availability of the carbohydrate polymers and thereby effective use of lignin component depend on delignification of plant material [6]. The characteristic feature of many phytopathogenic organisms is their ability to produce a variety of enzymes capable of degrading the complex polysaccharides of the plant cell wall and membrane constituents. Cell wall degrading enzymes released by pathogens are known to be responsible for pathogenesis. The ability of a pathogen to produce ligninolytic enzymes determines the degree of degradation of cell wall during pathogenesis. In literature, the main studies on pathogenic fungi include screening for secondary metabolites (phytotoxins), but not many have explored the possibility for the extracellular enzyme. During the survey it was observed that isolates of Alternaria infected the parthenium weed and caused leaf spot and leaf blight diseases. In virtue of the shortage of information about the enzymatic activity of pathogenic fungi isolated from it, this present study evaluated the potential of six isolates of Alternaria fungi for ligninolytic enzyme production.

\section{Material and methods}

\subsection{Isolation of Pathogens}

The fungal pathogens were isolated from the infected leaf portion of the parthenium weed. The leaves were cut into small portions and sterilized in 70 percent ethanol then washed in sterile distilled water for four to five times. Leaf portions were then placed on PDA medium plates supplemented with streptomycin sulfate. These were then incubated at $\pm 25^{\circ} \mathrm{C}$ for 7 days. Isolated fungi were aseptically transferred to PDA plates and the pure cultures were incubated at above conditions. The pure culture was maintained on PDA slants [2]. 


\subsection{Morphological Identification}

Lacto phenol cotton blue mount was used to study the morphological characteristics of the mycelium, conidia and perithecia of fungal strain and preliminarily identification was done with the help of standard literature $[7,8]$.

\subsection{Molecular Identification}

The Fungal pathogen was molecularly characterized by using the commercial service provided by Macrogen Inc., Advancing through Genomics, Korea. Fungus genomic DNA samples were extracted using an InstaGenetm Matrix (BIO-RAD.) The primers ITS1 primer (5TCCGTAGGTGAACCTGCGG-3) and ITS5 (5GGAAGTAAAAGTCGTAACAAGG-3) and ITS4 primer (5- TCCTCCGCTTATTGATATGC-3) were used for the PCR. The PCR reaction was performed with $20 \mathrm{ng}$ of genomic DNA as the template in a $30 \mu 1$ reaction mixture by using an EF-Taq (SolGent, Korea) as follows: activation of Taq polymerase at $95^{\circ} \mathrm{C}$ for 2 minutes, 35 cycles of $95^{\circ} \mathrm{C}$ for 1 minutes, $55^{\circ} \mathrm{C}$, and $72{ }^{\circ} \mathrm{C}$ for 1 minutes each were performed, finishing with a 10 -minute step at $72{ }^{\circ} \mathrm{C}$. The amplification products were purified with a multiscreen filter plate (Millipore Corp., Bedford, MA, USA). The purified PCR products of approximately $600 \mathrm{bp}$ were sequenced by using 2 primers. Sequencing reaction was performed using a PRISM BigDye Terminator v3.1 Cycle sequencing Kit. The DNA samples containing the extension products were added to Hi-Di formamide (Applied Biosystems, Foster City, CA). The mixture was incubated at $95{ }^{\circ} \mathrm{C}$ for $5 \mathrm{~min}$, followed by 5 min on ice and then analyzed by ABI Prism 3730XL DNA analyzer (Applied Biosystems, Foster City, CA) [9].

\subsection{Pathogenicity Test}

The pathogenicity was determined in vitro conditions. Healthy leaves of parthenium were used for inoculation. The leaves were washed with sterile distilled water and wiped with a cotton swab dipped in $70 \%$ alcohol. Mycelial discs taken from 5 days old colony were placed on leaves. The inoculated leaves were kept in sterilized moist chambers and incubated at $25^{\circ} \mathrm{C}$. Regular observations were made for the appearance of symptoms after 3 days of incubation [10].

\subsection{Detection of Extracellular Ligninolytic Enzyme Production}

Lignin physically surrounds and protects the carbohydrate polymers from enzymatic hydrolysis and is also the most recalcitrant component of plant cell wall [11]. The action of lignin degrading enzymes such as lignin peroxidases, manganese peroxidase and laccases play an important role in bringing about the degradation of lignin present in biomass. The presence of these enzymes in pathogenic fungi helps in the pathogenesis by the invasion of plant tissue.

Isolates from Parthenium hysterophorus (one Alternaria alternata isolate, two isolates of Alternaria macrospora and two isolates of Alternaria sp.) were screened quantitatively and qualitatively for Ligninolytic enzymatic production.

\subsubsection{Qualitative Assay}

\subsubsection{Azure-B agar (Lignin peroxidase and Mn peroxidase enzyme activity)}

One $\mathrm{cm}$ diameter plug cut from the growing edge of PDA cultures of selected isolates was centrally inoculated on the surface of azure B agar plate [Table 1]. The plates were incubated at $25 \pm 2^{\circ} \mathrm{C}$ for 7 days. The uninoculated plate served as a control. The production of lignin peroxidase and Mn peroxidase was recorded as clearance of blue colored medium.

Table 1. Composition of Azure B Agar Medium [4]

\begin{tabular}{ccc}
\hline Sr. No. & Component & Amount $(\mathrm{g} / \mathrm{L})$ \\
\hline 1. & $\mathrm{FeSO}_{4}$ & 0.001 \\
2. & Yeast Extract & 0.01 \\
3. & $\mathrm{CuSO}_{4} \cdot 5 \mathrm{H}_{2} \mathrm{O}$ & 0.001 \\
4. & $\mathrm{MnS}_{4} \cdot \mathrm{H}_{2} \mathrm{O}$ & 0.001 \\
5. & $\mathrm{KH}_{2} \mathrm{PO}_{4}$ & 1.0 \\
6. & $\mathrm{MgS0}_{4} \cdot 7 \mathrm{H}_{2} \mathrm{O}$ & 0.5 \\
7. & $\mathrm{CaCl}_{2} \cdot 2 \mathrm{H}_{2} \mathrm{O}$ & 0.01 \\
8. & $\mathrm{Azure} \mathrm{B} \mathrm{dye}^{2}$ & $0.02 \%$ \\
9. & Agar & 15.0 \\
10. & Distilled water & $1000.0 \mathrm{ml}$ \\
\hline
\end{tabular}

\subsubsection{Guaiacol Medium}

Laccase activity was also assessed by growing the fungi on solid medium with guaiacol as an indicator [Table 2]. $0.01 \%$ guaiacol was added to the solid medium (PDA) and incubated at $25^{\circ} \mathrm{C}$. Guaiacol positive reaction was indicated by the formation of a reddish brown halo.

Table 2. Composition of Guaiacol Agar Medium [12]

\begin{tabular}{ccc}
\hline Sr. No. & Component & Amount $(\mathrm{g} / \mathrm{L})$ \\
\hline 1. & Potato (peeled) & $200.0 \mathrm{~g}$ \\
2. & Dextrose & $20.0 \mathrm{~g}$ \\
3. & Guaiacol & $0.1 \mathrm{~g}$ \\
3. & Agar & $20.0 \mathrm{~g}$ \\
4. & Distilled water & $1000 \mathrm{ml}$ \\
\hline
\end{tabular}

\subsubsection{Quantitative Assay}

\subsubsection{Azure B Assay for Lignin Peroxidase}

Azure B as a substrate to assay lignin peroxidase is commonly used by various researchers [13]. Reactions were carried out in $3 \mathrm{ml}$ cuvettes containing1 $\mathrm{ml}$ of $125 \mathrm{mM}$ sodium tartrate buffer ( $\mathrm{pH} 4.0), 500 \mu \mathrm{l}$ of $0.160 \mathrm{mM}$ Azure $\mathrm{B}, 500 \mu \mathrm{l}$ of enzyme extract and $500 \mu \mathrm{l}$ of $2 \mathrm{mM} \mathrm{H}_{2} \mathrm{O}_{2}$. The optical density (OD) decrease was read at exactly $651 \mathrm{~nm}$.

\subsubsection{Manganese peroxidise Assay}

Manganese peroxidise activity was assayed using $0.5 \mathrm{ml}$ of sodium tartrate buffer ( $\mathrm{pH} 5$ ), $0.5 \mathrm{ml}$ of $100 \mu \mathrm{M}$ guaiacol, $1 \mathrm{ml}$ of distilled water, $0.1 \mathrm{ml}$ of culture filtrate, and $0.5 \mathrm{ml}$ of hydrogen peroxide $(30 \% \mathrm{w} / \mathrm{v})$ containing a reaction mixture and by reading its optical density at $465 \mathrm{~nm}$ [14]. 


\subsubsection{Guaiacol assay method for laccase assay}

Guaiacol has been reported as the efficient substrate for laccase assay. The intense brown color development due to oxidation of guaiacol by laccase can be correlated to its activity often read at $450 \mathrm{~nm}$. Guaiacol $(2 \mathrm{mM})$ in sodium acetate buffer (10mM pH 5.0) was used as the substrate. The reaction mixture contained $3 \mathrm{ml}$ acetate buffer, $1 \mathrm{ml}$ guaiacol and $1 \mathrm{ml}$ enzyme source and enzyme blank contained $1 \mathrm{ml}$ of distilled water instead of enzyme source. The mixture was incubated at $30^{\circ} \mathrm{C}$ for $15 \mathrm{~min}$ and absorbance was read at 450nm blank using UV spectrophotometer [15].

For these enzymes, 1 activity unit was defined as the amount of enzyme necessary to oxidize $1 \mu \mathrm{mol}$ substrate/min.

\section{Results}

During the extensive surveys conducted in the Kurukshetra district of Haryana in October 2013, the infestation of parthenium was recorded in crops, uncultivated areas and roadsides. A congress grass population was found affected by various leaf spots and leaf blight diseases at different parts of Kurukshetra. The infected part on PDA yielded fungal pathogens and the microscopic study revealed that the isolates belong to the genus Alternaria. The symptoms, cultural, morphological and molecular characteristics of the fungal isolates are described below.

\subsection{Alternaria Alternata}

The symptoms appeared as small, central and marginal brown or black spots scattered on leaves. The spots became irregular in shape. When their size increased they turned brown to black in colour. Several such lesions may coalesce resulting in leaf drying. Culture grey green in colour with white margins and becoming black at maturity. Conidiophores light brown to golden brown, simple, branched, septate, straight or curved, smooth walled. Conidia light brown to olivaceous, borne long acropetal chains, ovoid or obclavate with a long or short beak, or ellipsoidal and without the beak, smooth to echinulate, muriform with transverse and longitudinal septa. The beak, when present, is always smaller and lighter in colour than the conidial body. Diseased specimens and culture have been deposited at CAB International Mycological Institute, UK with reference No. 502784 and IIBC, Ascot, UK.

\subsection{Alternaria macrospora MKP2}

A pathogen was isolated on PDA media from infected leaves and it yielded grey colonies on PDA [10]. The morphological identification showed that mycelium was septate, hyaline and branched, conidia were solitary, dark brown, straight or slightly flexuous, muriform and ellipsoidal with the tapering long beak. The size of conidia ranged from 17.5-62.5×10-17.5 $\mu \mathrm{m}$ with 1-6 transverse septa and 0-2 longitudinal septa. The size of the beak ranged from
$0-20 \times 5-7.5 \mu \mathrm{m}$. Chlamydospores numerous in nature and in culture, dark brown; a chlamydospore initially may be one-celled, intercalary or terminal on a hypha, round with a thickened wall but often including several adjacent cells on hypha, eventually cells dividing into several planes and chlamydospores becoming many celled and irregular in shape. The identification of the pathogen has been confirmed from the CABI International Mycological Institute, UK with reference No. 503549 and the results showed that the top matches at $100 \%$ identity to two sequences of Alternaria species, neither of which relate to published strains. Thereafter matches were only at $98 \%$ identity to various members of the genus, including $A$. macrospora, $A$. solani, $A$. dauci, A. crassa, A. porri and others. Molecular analysis of the ITS1-5.8S-ITS2 rDNA region was carried out to confirm the species identity of the pathogen. The fungal pathogen was molecularly characterized by using the commercial service provided by Macrogen Inc., Advancing through Genomics, Korea. The molecular identification (ITS rDNA sequence analysis) showed the similarity of isolate with $A$. macrospora strain B isolated from Cotton plant infected with leaf blight disease. Sequence has been submitted to NCBI with GenBank accession number KM213867. In vitro pathogenicity of the isolated pathogen was determined and the typical disease symptoms were observed on leaves in a lab. The inoculated pathogen was re-isolated, thus confirming the pathogenicity of $A$. macrospora to Parthenium hysterophorus and usual Koch's postulates.

\subsection{Alternaria macrospora MKP4}

Colonies are grey green in colour on PDA. The mycelium was septate, hyaline and branched. Conidia were solitary, dark brown, straight or slightly flexuous, muriform and ellipsoidal with the tapering long beak. The size of conidia ranged from $50-87.5 \times 7.5-17.5 \mu \mathrm{m}$ with 1-6 transverse septa and 0-3 longitudinal septa. The size of the beak ranged from 7.5-75 $\times 2.5-7.5 \mu \mathrm{m}$. The conidial morphology of Alternaria macrospora strain MKP4 is in agreement with those described by Ellis [7]. Culture has been identified from the Macrogen Inc., Advancing through Genomics, Korea and the sequence has been deposited to the NCBI gene bank with accession number KM514669. Koch postulates have been proven from in vitro pathogenicity test.

\subsection{Alternaria sp. PMK1}

Leaf spot yielded a greenish grey fungal colony with abundant aerial mycelium on PDA and PeDA [10]. The mycelium was septate, hyaline and branched. Conidia were solitary, rarely in chains of 2-3, dark brown, straight or slightly flexous, muriform with the small beak. The size of conidia ranged from $12.5-42.5 \times 10-25 \mu \mathrm{m}$ with 1 to 8 transverse septa and 1 to 2 longitudinal septa, and 1 tangential septum. The conidial beak $(2-27.5 \times 5-10 \mu \mathrm{m})$ was pale brown, septate and swollen at the apex. Conidiophores are brown, straight to geniculate, up to $75 \mu \mathrm{m}$ long, $7.5 \mu \mathrm{m}$ thick and scar present at the point of bearing conidia. Based 
on these characteristics, the fungus was identified as Alternaria sp. [7]. The identification of the pathogen has been confirmed from CABI, International Mycological Institute, UK (IMI accession No. 504470) and Macrogen Inc., Advancing through Genomics, Korea. Molecular analysis of the ITS1-5.8S-ITS2 rDNA region carried out at CABI UK confirmed the pathogen as Alternaria sp. Subsequently, however on submitting the pathogen isolate to Macrogen Inc., Korea sequence analysis doesn't show any similarity with published strains and the best match $(99 \%)$ was with unpublished strain of Alternaria alternata strain S-f6 (HM165489). The Sequence has been submitted to NCBI with GenBank accession number KT192437.

\subsection{Alternaria sp. PMK2}

Leaf spot yielded a dark grey fungal colony with abundant aerial mycelium on PDA. The mycelium was septate, hyaline and branched. Conidia were solitary, dark brown, straight or slightly flexous, muriform with tapering long, filiform, hyaline and septate beak. The size of conidia ranged from 62.5-120 x 10-25 $\mu \mathrm{m}$ with 3 to 9 transverse septa and 2 to 5 longitudinal septa. The size of the beak ranged from $25-127.5 \times 5-7.5 \mu \mathrm{m}$ sometimes swollen at the apex, often much longer than the body of the conidia. The conidial morphology of Alternaria sp. PMK2 is in agreement with those described by Ellis [7]. Conidiophores are dark brown, straight to geniculate, arises in clusters, scar present at the point of bearing conidia. Based on these characteristics, the fungus was identified as Alternaria sp. The identification of the pathogen has confirmed from CABI, International Mycological Institute, UK (IMI accession No. 504469) and Macrogen Inc., Advancing through Genomics, Korea as
Alternaria sp. PMK2. The Sequence has submitted to NCBI with accession number KT192438.

\subsection{Production of Cell Wall Degrading Enzymes}

The use of simpler solid media permits the rapid screening of large populations of fungi for the presence or absence of specific enzymes. The five pathogenic Alternaria fungi were isolated from parthenium plants. All isolates were sub cultured routinely and maintained in the department. The isolates of filamentous fungi were screened for production of laccase, manganese peroxidase and lignin peroxidase enzymes qualitatively, on agar media containing specific substrates and quantitatively in liquid medium containing parthenium as substrate. Each isolate was able to produce one or the other Ligninolytic enzymes, some of the pathogens were able to produce all three Ligninolytic enzymes.

\subsubsection{Qualitative Assay}

\subsubsection{Laccase (Guaiacol oxidation)}

Guaiacol oxidation is one of the most convenient qualitative assay for Ligninolytic enzyme production among fungi. Five pathogenic fungal isolates of parthenium were screened for guaiacol oxidation and radial growth rate on agar plates containing guaiacol as an aromatic model compound. Results showed that all the fungal isolated from parthenium exhibited an ability to oxidize guaiacol, halo of intense brown colour was formed under and around the fungal colonies (positive for guaiacol oxidation), indicating the presence of ligninolytic enzymes (Laccase) Figure 1.

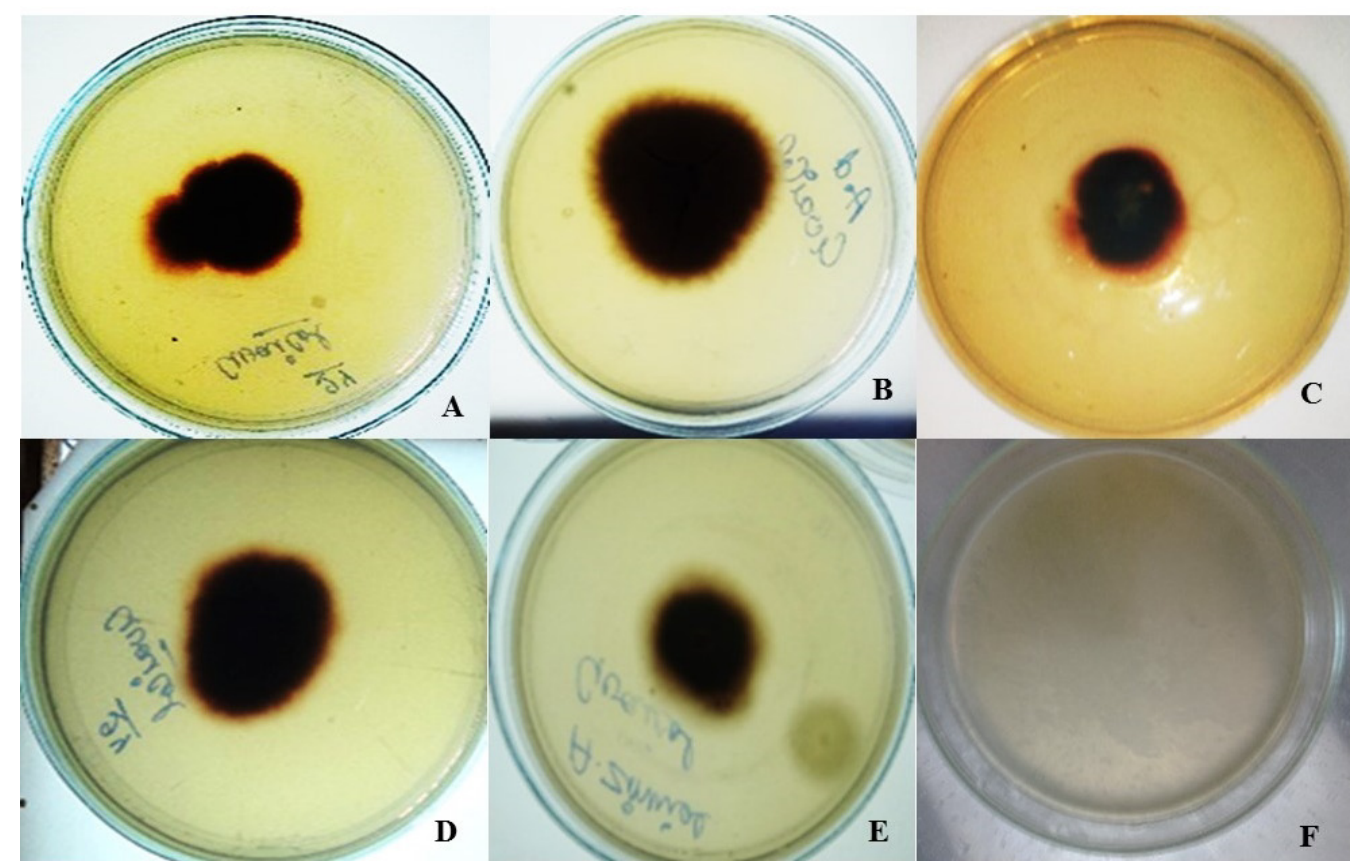

Figure 1. Laccase activity on Guaiacol Agar media; (A) Alternaria alternata; (B) Alternaria macrospora MKP2; (C) Alternaria macrospora MKP4; (D) Alternaria sp. PMK1; (E) Alternaria sp. PMK2; (F) Control 


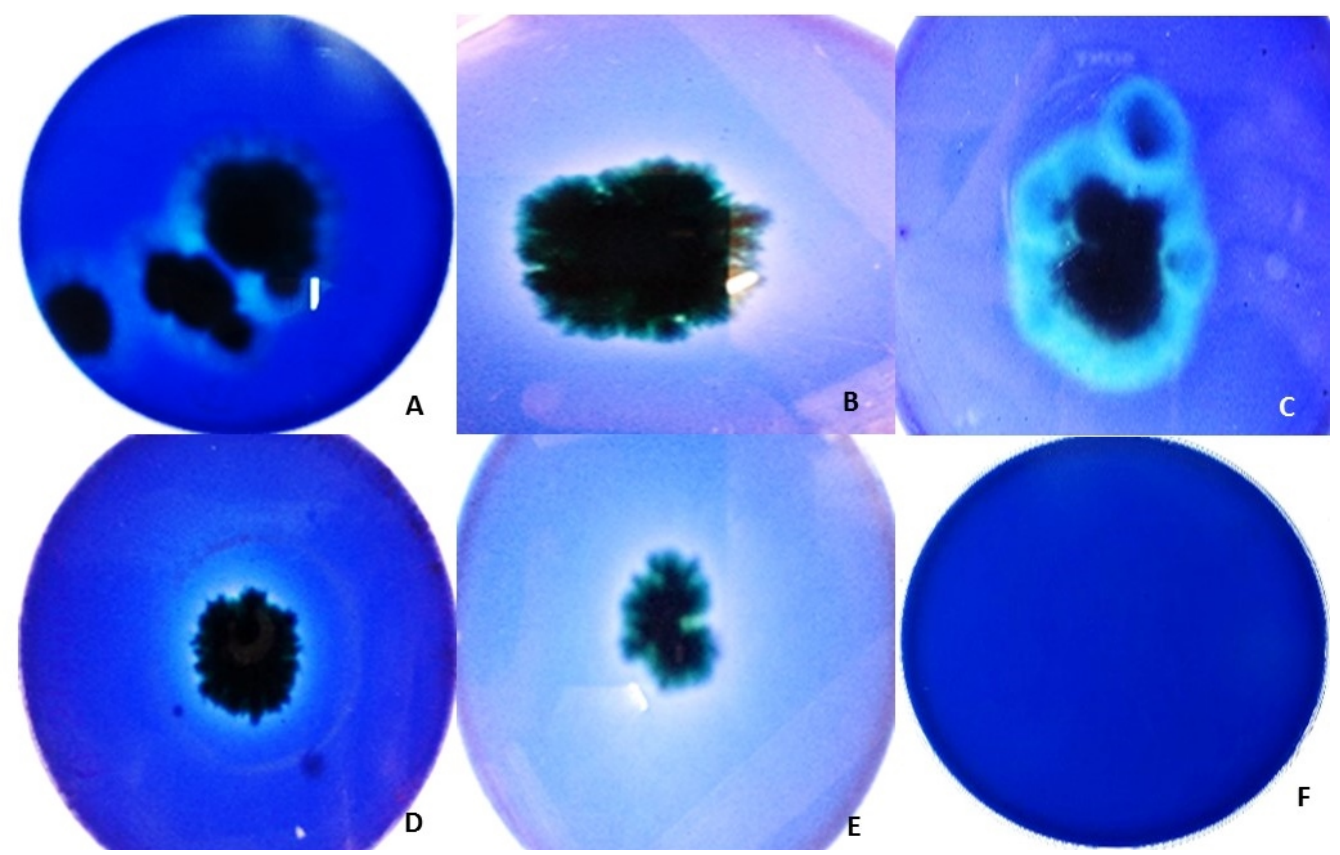

Figure 2. LiP and MnP activity on Azure B Agar media; (A) Alternaria alternata; (B) Alternaria macrospora MKP2; (C) Alternaria macrospora MKP4; (D) Alternaria sp. PMK1; (E) Alternaria sp. PMK2; (F) Control

\subsubsection{Lignin peroxidase (LiP) and Manganese peroxidase $(\mathrm{MnP})$}

Decolourization of the dye Azure-B by fungi has been positively correlated with production of lignin peroxidase and Manganese peroxidase. In solid plate screening all the five Alternaria pathogens decolorized the Azure B dye and exhibited an ability to produce lignin peroxidase and Manganese peroxidase enzymes. The results of Azure B dye degradation on the solid medium are depicted in Figure 2.

\subsubsection{Quantitative Enzymatic Assay}

In view of the results obtained, the production of main ligninolytic enzymes ( $\mathrm{LiP}, \mathrm{MnP}$ and laccase), was studied in liquid media using parthenium as the substrate for 20 days. An aliquot of the sample was aseptically removed at three days interval and assayed for the enzymes LiP, MnP and laccase by the methods described in enzyme assays. The result showed that, laccase and lignin peroxidase enzymes were detected in all the five isolates. Manganese peroxidase was absent in one of the isolate i.e. Alternaria sp. PMK1 while other four isolates were found to be positive for $\mathrm{MnP}$ enzyme [Table 3].

The enzyme activity was measured every day after the third day of incubation and continued until the decrease in activity level was observed. The laccase enzyme activity was high on the 15th day of incubation and Alternaria sp. PMK2 expressed a high titer $(26.50 \mathrm{U} / \mathrm{ml})$ of laccase on the $15^{\text {th }}$ day of incubation followed by Alternaria alternata $(11.61 \mathrm{U} / \mathrm{ml})>$ Alternaria macrospora MKP4 $(3.77 \mathrm{U} / \mathrm{ml})$, Alternaria macrospora MKP2 $(2.67 \mathrm{U} / \mathrm{ml})$ and the least laccase activity was observed in Alternaria sp. PMK1 $(2.0 \mathrm{U} / \mathrm{ml})$. The lignin peroxidase enzyme production started on the $6^{\text {th }}$ day of incubation and highest activity was recorded on the $10^{\text {th }}$ day of incubation. Out of the five isolates Alternaria macrospora MKP2 and Alternaria alternata highest LiP activity i.e. $0.25 \mathrm{U} / \mathrm{ml}$ and $0.23 \mathrm{U} / \mathrm{ml}$ respectively, least LiP enzyme activity was recorded in Alternaria macrospora MKP4 $(0.16 \mathrm{U} / \mathrm{ml})$. Alternaria sp. PMK1 and Alternaria sp. PMK2 produced LiP in the same range of $0.19(\mathrm{U} / \mathrm{ml})$. MnP production was started on the $15^{\text {th }}$ day of incubation and the highest activity was also recorded on $15^{\text {th }}$ day of incubation and after that, the decrease occurred in enzymatic activity. The highest enzymatic activity was recorded in Alternaria sp. PMK2 $(0.3 \mathrm{U} / \mathrm{ml})$ followed by Alternaria alternata $(0.25 \mathrm{U} / \mathrm{ml})>$ Alternaria macrospora MKP4 $(0.144 \mathrm{U} / \mathrm{ml})$ and Alternaria macrospora MKP2 (0.12U/ml). This activity was absent in Alternaria sp. PMK1. The Ligninolytic enzymes produced by these fungal pathogens may be seen as pathogenic in the penetration of the parthenium plant material and could to be useful in biocontrol of parthenium weed.

Table 3. LiP, MnP and Laccase activities of the isolated pathogens screened in liquid cultures containing parthenium as substrate.

\begin{tabular}{cccc}
\hline Isolates & $\mathrm{LiP}(\mathrm{U} / \mathrm{ml})$ & $\mathrm{MnP}(\mathrm{U} / \mathrm{ml})$ & Laccase $(\mathrm{U} / \mathrm{ml})$ \\
$\begin{array}{c}\text { Alternaria } \\
\text { alternata }\end{array}$ & $0.23^{*} \pm 0.09^{* * \mathrm{bw}}$ & $0.25 \pm 0.21^{\mathrm{cw}}$ & $11.61 \pm 0.07^{\mathrm{aw}}$ \\
$\begin{array}{c}\text { Alternaria } \\
\text { macrospora } \\
\text { MKP2 }\end{array}$ & $0.25 \pm 0.035^{\mathrm{by}}$ & $0.12 \pm 0.15^{\mathrm{cy}}$ & $2.67 \pm 0.14^{\mathrm{ay}}$ \\
$\begin{array}{c}\text { Alternaria } \\
\text { macrospora } \\
\text { MKP4 }\end{array}$ & $0.16 \pm 0.25^{\mathrm{bx}}$ & $0.144 \pm 0.05^{\mathrm{cx}}$ & $3.77 \pm 0.05^{\mathrm{ax}}$ \\
$\begin{array}{c}\text { Alternaria } \text { sp. } \\
\text { PMK1 }\end{array}$ & $0.19 \pm 0.16^{\mathrm{bz}}$ & - & $2.0 \pm 0.06^{\mathrm{az}}$ \\
$\begin{array}{c}\text { Alternaria } \text { sp. } \\
\text { PMK2 }\end{array}$ & $0.19 \pm 0.52^{\mathrm{bv}}$ & $0.3 \pm 0.03^{\mathrm{cv}}$ & $26.50 \pm 0.15^{\mathrm{av}}$ \\
\hline
\end{tabular}

*- Values, including are means of three replicates; **-Standard deviation; Within three different enzymes with five different microorganisms tested; different letters are significantly $(\mathrm{p}<0.05)$ different. 


\section{Discussion}

In the present study, the fungal pathogens of parthenium weed were screened qualitatively and quantitatively for lignin degrading enzymes production. The elaboration of an array of cell wall splitting enzymes helps the pathogen for easy penetration of the host cell wall and subsequent colonization [16]. Lignin found in middle lamella, the secondary cell wall of xylem vessels and the fibers that strengthen the plants. In fungi Ligninolytic enzymes probably have more roles in fungal plant-pathogen/host interaction and stress defence and lignin degradation [17]. Only a small group of microorganisms are capable of degrading lignin as the lignin is more resistant to enzymatic degradation than other plant substances. Most of the ligninolytic enzymes reported thus far are of fungal origin, especially from white rot fungi but some pathogenic ascomycetes and deutromycetes are also known to produce lignin degrading enzymes [18]. In our study, Alternaria pathogens of parthenium were able to produce ligninolytic enzymes which may contribute to the pathogenesis against this weed. Numbers of cell wall degrading enzymes have been shown to be produced by plant pathogens [19], which are known to facilitate cell wall penetration and tissue maceration in host plants. Since all the species of Alternaria are intercellular in the host, the productions of these enzymes appears to facilitate the dissolution of host cell wall and middle lamella and help entry and establishment of the pathogen in the host and are possibly responsible for playing a vital role in pathogenesis through cell wall degradation and disintegration of tissues [20]. In the present study, the virulent pathogens isolated from parthenium weed produced Ligninolytic enzymes using parthenium as a carbon source, indicating the importance of the cell wall degrading enzymes in pathogenesis against parthenium weed. This study will serve to understand the role of ligninolytic enzymes in pathogenicity against parthenium weed.

\section{Conclusions}

In the present work pathogenic fungal species from parthenium, producing ligninolytic enzymes were documented. The results showed that the different Alternaria species have different ligninolytic systems. These fungal isolates of Alternaria are reported for the first time as the efficient producers of Ligninolytic enzymes. The excellent enzymatic activity and pathogenesis of these isolates accentuate their potential in biocontrol of devastating weed parthenium.

\section{Acknowledgements}

The authors are thankful to the University Grants Commission, New Delhi for providing financial assistance in the form of Maulana Azad National Fellowship for minority students.

\section{REFERENCES}

[1] M. Kaur, N. K. Aggarwal, V. Kumar, R. Dhiman. Effects and Management of Parthenium hysterophorus a weed of global significances, International Scholarly Research Notices, doi.org/10.1155/2014/368647, 2014.

[2] N. K. Aggarwal, M. Kaur, V. Kumar, A. Saini. Mycobiota associated with Parthenium hysterophorus isolated from North India, Indian Journal of Weed Science, vol. 46, pp. 155-160, 2014.

[3] G.N. Agrios. Plant Pathology, 5th ed, Elsevier Academic Press, San Francisco, 2005.

[4] P. Sarkar. Elena Bosneaga1 and Manfred Auer Plant cell walls throughout evolution: towards a molecular understanding of their design principles, Journal of Experimental Botany, vol. 60 , no. 13 , pp. 3615-3635, 2009.

[5] M. Narkhede, R, Mahajan, K. Narkhede. Ligninolytic enzyme production and remazol brilliant blue $\mathrm{r}$ (rbbr) decolorization by a newly isolated white rot fungus basidiomycota. SPP. L-168, International Journal of Pharma and BioSciences, vol. 4, no. 1, pp. 220-228, 2013.

[6] J. Rytioja, K. Hildén, J. Yuzon, A. Hatakka, R. P. de Vries, M. R. Makela. Plant-Polysaccharide-Degrading Enzymes from Basidiomycetes, Microbiology and Molecular Biology Reviews, vol. 78, no. 4, pp. 614-649, 2014.

[7] M. B. Ellis. Dematiaceous Hyphomycetes, Commonwealth Mycological Institute, England, 1971.

[8] M. B. Ellis. More Dematiaceous Hyphomycetes, Commonwealth Mycological Institute, England, 1976.

[9] M. Satou, M. Ichinoe, F. Fukumoto, N. Tezuka, S. Horiuchi. Fusarium Blight of Kangaroo Paw (Anigozanthos spp.) caused by Fusarium chlamydosporum and Fusarium semitectum, Journal of Phytopathology, vol. 149, pp. 203-206, 2001.

[10] K. R. Aneja, S. A. Khan, S. Kaushal. Management of Horse purslane (Trianthema portulacastrum L.) with Gibbago trianthemae Simmons in India. In: Proceedings of the $X$ International Symposium on Biological Control of Weeds, Montana State University, Bozeman, Montana, pp. 27-33, 2000 .

[11] A. Sanchez. Lignocellulosic residues: Biodegradation and bioconversion by fungi, Biotechnology Advances, vol. 27, pp. 185-194, 2009.

[12] L. L. Kiiskinen, M. Ratto, K. Kruus. Screening for novel laccase-producing microbes, Journal of Applied Microbiology, vol. 97, pp. 640-646, 2004.

[13] F. S. Archibald. A new assay for lignin-type peroxidase employing the dye Azure B. Applied Environmental Microbiology, vol. 58, no. 31, pp. 6-10, 1992.

[14] A. Parzeznski, V. B. Hynn, R. L. Crawford. Comparison of lignin I and peroxidase M2 from the white rot fungus Phanerochete chrysosporium, Archives of Biochemistry and 
Biophysics, vol. 244, pp. 750-765, 1986.

[15] A. Jhadav, K. K. Vamsi, Y. Khairnar, A. Boraste, N. Gupta.Optimization of production and partial purification of laccase by Phanerochaete chrysosporium using submerged fermentation, International Journal of Microbiology Research, vol. 1, pp. 09-12, 2009. C. F.

[16] R. N. Goodman, Z. Kiraly, M. Zaitlin. The Biochemistry and Physiology of Infectious Plant Disease, D. Van Nostrand Co., Inc. Princeton, New Jersey, pp. 354, 1967.

[17] Thurston. The structure and function of fungal laccases, Microbiology, vol. 140, pp. 19-26, 1994.
[18] P.D. Sharma. Plant Pathology. 2nd ed., Rastogi Publications, India, 2008.

[19] Y. Chenglin, S. C. William, E. S. Carl. Purification and characterization of a polygalacturanase produced by Penicillium expansum in apple fruit, Phytopathology, vol. 86, pp. 1160-1166, 1996.

[20] T. Anand, R. Bhaskaran, T. Raguchander, G. Karthikeyan, M. Rajesh, G. Senthilraja. Production of cell wall degrading enzymes and toxins by Colletotrichum capsici and Alternaria alternata causing fruit rot of chillies, Journal of Plant Protection Research, vol. 48 no. 4, pp. 437-451, 2008. 